\title{
Effect of Plant Growth Regulators on Vegetative Parameter of Marigold cv. Calcutta Marigold under Konkan Conditions
}

\author{
T. T. Narute ${ }^{1 *}$, Y. R. Parulekar ${ }^{1}$ and T. K. Narute $^{2}$ \\ ${ }^{1}$ College of Horticulture, Dr. Balasaheb Sawant Konkan Krishi Vidyapeeth, Dapoli-415712, \\ District: Ratnagiri (M. S), India \\ ${ }^{2}$ Department of Plant Pathology, Mahatma Phule Krishi Vidyapith, Rahuri-413705, District: \\ Ahmednagar, Maharashtra, India \\ *Corresponding author
}

\section{A B S T R A C T}

\section{Keywords}

African marigold,

Plant growth

regulators,

Vegetative

parameters, Konkan condition

Article Info

Accepted:

26 September 2020

Available Online:

10 October 2020
The present experiment was conducted at Department of Floriculture and Landscape Architecture, College of Horticulture, Dr. Balasaheb Sawant Konkan Krishi Vidyapeeth, Dapoli Dist. Ratnagiri, (Maharashtra State) during Rabi season of the year 2019-20. The experiment was laid out in Randomized Block Design with three replications comprising nine treatments viz., $\mathrm{GA}_{3}$ (100 ppm and $\left.200 \mathrm{ppm}\right)$, TRIA (20 ppm and $\left.30 \mathrm{ppm}\right), \mathrm{CCC}$ (4000 ppm and $5000 \mathrm{ppm}$ ) and NAA (10 ppm and $20 \mathrm{ppm})$ along with control on marigold cv. Calcutta Marigold. The results of the present experiment are statistically significant difference was recorded on growth and yield of marigold plants as a result of various plant growth regulator treatments applied. Among all the treatments, maximum plant height $(82.26 \mathrm{~cm})$, plant spread $(92.52 \mathrm{~cm})$, a greater number of branches $(56.02)$, a greater number of leaves (420.60) and maximum fresh and dry weight (190.37 g/plant) and (22.84 g/plant) were recorded in $\mathrm{GA}_{3} @ 100$ ppm. Next to this it was followed by the $\mathrm{GA}_{3} @ 200$ ppm treatment with height of $(78.68 \mathrm{~cm})$, plant spread $(91.00 \mathrm{~cm})$, number of branches (55.98), number of leaves (419.20) and fresh and dry weight (189.17 g/plant) and (22.70 $\mathrm{g} /$ plant) respectively, as compare to other treatments and control. Both the treatments of $\mathrm{GA}_{3} @ 100$ and 200 ppm were found statistically significant at all levels over all other treatments and were on same par with each other for vegetative plant characters under study.

\section{Introduction}

The flowers are the natures beloved gift to human being. Flowers are recognized as a token and symbol of love, respect, purity, beauty, peace and passion. The demand for floriculture products is steadily increasing both in domestic as well as in export markets.
In India, floriculture industry is growing day by day both in terms of area as well as production. In India, the area under cultivation of floriculture is about $3,39,000$ hectors with the production of $19,91,000$ tonnes loose flowers and 8,67,000 tonnes of cut flowers (Anonymous, 2019). With the export of 19726.57 MT of floriculture 
produce worldwide with the net income of Rs. 571.38 crores (Anonymous, 2019). The largest city in Konkan coast, Mumbai, the State capital of Maharashtra is a potential market for all agricultural products and flowers too. There are five other districts in the region viz. Palghar, Thane, Raigad, Ratnagiri, Sindhudurg. Konkan is known as non-traditional area for production of commercial flowers. In the region, only 528 ha area is under different flower crops with a production of 3140.95 MT (Anonymous, 2019). Marigold is an important flower widely accepted since long back. Plant height, plant spread, number of branches, number of leaves, fresh weight and dry weight are the genetical constituents of plants. African marigold (Tagetes erecta L.) belongs to family Asteraceae. The genus Tagetes contains nearly 40 species, all are annuals. Marigold is becoming popular in various parts of Maharashtra including Konkan. In Konkan, the area under marigold is increasing both during kharif as well as rabi season and is being cultivated as cash crop. The production is aimed in a festival period so that the producer can get attractive prices for his produce.

The climatic conditions of Konkan region are quite aberrant. Among the plants growth regulators, gibberellins (GA) are the most widely used and proven growth regulators in horticulture crops.

Among the gibberellins, $\mathrm{GA}_{3}$ influences a range of development processes like germination, breaking dormancy, stem elongation, flowering, enzyme induction, leaf and flower senescence, etc. (Brian, 1959) and (Gupta and Chakrabarty, 2013). The plant growth regulator triacontanol (TRIA) has a great role in enhancing growth, yield, photosynthesis, nitrogen fixation, enzymatic activities and level of free amino acids, reducing sugars and soluble proteins. TRIA application increases plant growth, the number of inflorescences and the quality of flower in Chrysanthemum (Skogen, et al., 1982) and (Naeem, et al., 2012). 1Naphthalene acetic acid i.e. NAA is a plant growth regulator used for thinning in horticulture crops as well as used for root formation Widayani and Ansari, 1990 and Khandekar, et al., 2017. Cycocel (2Chloroethyl trimethyl ammonium chloride) i.e. CCC an anti-gibberellin gives dwarfing effect and restricts the growth of the internodes and regulates the plant physiology Cockshull and Emden, 1969 and Bhat, et al., 2011. Generally, it does not affect the yield of flowers. Keeping in view the scope and increased demand of African marigold (Tagetes erecta L.) flowers, the present investigation was undertaken to evaluate the effect of different plant growth regulators on growth parameters and yield of this crop under Konkan conditions

\section{Materials and Methods}

A The present investigation was conducted during rabi season, of the year 2019-20 at Department of Floriculture and Landscape Architecture, College of Horticulture, Dr. Balasaheb Sawant Konkan Krishi Vidyapeeth, Dapoli to elucidate information on effect of different growth regulators on yield of marigold. This experiment was carried out in randomized block design (RBD) replicated thrice with 9 treatments. The crop African marigold variety Calcutta Marigold was taken for the study with the treatments.

The stock solution was prepared before actual application of treatments. For preparing 1000 $\mathrm{ml}$ of stock solution, $1 \mathrm{~g} \mathrm{GA}_{3}$ was added and dissolved in $10 \mathrm{ml}$ of $\mathrm{NaOH}$ solution and then this solution was transferred into one litre of volumetric flask and then total volume one litre was prepared with distilled water. For preparation of concentration of 100 ppm $\mathrm{GA}_{3}$ 
solution, $100 \mathrm{ml}$ of stock solution was taken in volumetric flask and 1 lit volume was made up by using distilled water. By adopting similar procedure, the $200 \mathrm{ppm} \mathrm{GA} 3$ solution was prepared.
The remaining three plant growth regulators (PGR) were available in liquid form, therefore these were dissolved in distilled water. Accordingly, different concentrations were prepared.

\section{Plant growth regulator solutions were prepared as follows}

\begin{tabular}{|c|c|c|c|}
\hline Chemicals & Conc. & Chemical used in ml & Water used in ml \\
\hline Triacontanol 0.1 \% W/W & $20 \mathrm{ppm}$ & 20 & 980 \\
\hline Triacontanol 0.1 \% W/W & $30 \mathrm{ppm}$ & 30 & 970 \\
\hline CCC 50 \% SL & $4000 \mathrm{ppm}$ & 08 & 1000 \\
\hline CCC 50 \% SL & $5000 \mathrm{ppm}$ & 10 & 1000 \\
\hline NAA 4.5 \% SL & $10 \mathrm{ppm}$ & 0.24 & 1000 \\
\hline NAA 4.5 \% SL & $20 \mathrm{ppm}$ & 0.48 & 1000 \\
\hline
\end{tabular}

The following methods were used for observations

\section{Vegetative parameters}

The treatment of $\mathrm{GA}_{3}$, TRIA, CCC and NAA on growth of marigold were recorded regularly at the interval of 30 days in respect of the following growth parameters.

\section{Plant height (cm)}

The effect of individual treatment on plant height was measured in each treatment and replication at an interval of one month on selected plants. The plant height was measured from the base of main stem to the tip of plant with the help of meter scale and expressed in centimetres.

\section{Plant canopy spread (cm)}

The observation on effect of different treatments in all replications on plant canopy i.e. the horizontal plant spread was measured in centimetres in North-South and East-West direction of selected plants and the average was worked out. The observations were recorded at an interval of one month.

\section{Number of branches per plant}

The number of branches (Primary and Secondary) in selected plants from each treatment and replication were counted and the average was worked out.

\section{Number of leaves per plant}

The number of leaves were counted on selected plants of each treatment and replication and recorded at monthly interval. The average was worked out.

\section{Fresh weight of plant (g/plant)}

After harvesting of marketable flowers from each treatment, the fresh weight of selected and labeled plants was uprooted smoothly and recorded the fresh weight in gram $(\mathrm{g})$ to access the effect of individual treatment on plant mass.

\section{Dry weight of plant (g/plant)}

After weighing the fresh weight of selected and labelled plants from individual treatments, further these plants were dried in hot air oven at $40^{\circ} \mathrm{C}$ for $24 \mathrm{hrs}$ until its colour changed from green-yellow to brown to 
access effect of individual treatment on dry matter of plant. The observations were recorded in gram (g) with the help of weighing balance.

\section{Results and Discussion}

\section{Vegetative Parameters}

\section{Plant height (cm)}

The scrutiny of the data presented in Table 1 elucidated that there was a significant difference between different treatments of plant growth regulators and their concentrations carried on marigold plant cv. Calcutta Marigold at different phases of crop growth viz., 30 DAT, 60 DAT, 90 DAT and 120 DAT respectively in regards to plant height.

The data collected at 30 DAT, visibly signified that, there was no effect of any PGR treatment immediately after spray i.e. all the treatments at 30 DAT were non-significant. However, the plant spread was in the range of $21.00 \mathrm{~cm}$ in $\mathrm{T}_{5}$ to $28.31 \mathrm{~cm}$ in $\mathrm{T}_{1}$. At $60 \mathrm{DAT}$, it was evident from the data that the difference in plant height in different PGR treatments was significant. The maximum average height $(50.99 \mathrm{~cm})$ was recorded in $\mathrm{T}_{7}$ - NAA @ 10 ppm, followed by $\mathrm{T}_{1}-\mathrm{GA}_{3} @$ 100 ppm $(50.74 \mathrm{~cm}), \mathrm{T}_{9}-$ Control $(50.50 \mathrm{~cm})$, $\mathrm{T}_{8}$ - NAA @ 20 ppm $(48.18 \mathrm{~cm})$ which were at par with each other. The lowest plant height $(34.03 \mathrm{~cm})$ was recorded in $\mathrm{T}_{5}-\mathrm{CCC} @ 4000$ ppm which was at par with $\mathrm{T}_{6}-\mathrm{CCC} @ 5000$ ppm $(35.77 \mathrm{~cm})$.

The plant height measured at 90 DAT varied from $39.10 \mathrm{~cm}$ to $79.90 \mathrm{~cm}$ among different treatments. The maximum average height $(79.90 \mathrm{~cm})$ was observed in $\mathrm{T}_{1}-\mathrm{GA}_{3} @ 100$ ppm treated plants which was at par with $\mathrm{T}_{7}$ NAA @ 10 ppm $(77.45 \mathrm{~cm})$ and $\mathrm{T}_{2}-\mathrm{GA}_{3} @$ 200 ppm $(75.59 \mathrm{~cm})$. The minimum plant height was recorded in treatment $\mathrm{T}_{5}$ i.e. $\mathrm{CCC}$ @ 4000 ppm $(44.87 \mathrm{~cm})$ and $\mathrm{T}_{6}-\mathrm{CCC} @$ 5000 ppm $(39.10 \mathrm{~cm})$.

Further the final plant height was examined at 120 DAT, which exhibited significantly different amongst the treatments. The maximum average height $(82.26 \mathrm{~cm})$ was observed in $\mathrm{T}_{1}-\mathrm{GA}_{3} @ 100$ ppm treated plants which was on par with $\mathrm{T}_{7}$ - NAA @ 10 ppm (79.06 cm), T - GA 3200 ppm (78.68 $\mathrm{cm})$ and $\mathrm{T}_{3}$ - TRIA @ 20 ppm $(76.92 \mathrm{~cm})$. Minimum plant height was recorded in $\mathrm{T}_{5}$ CCC@ @ 4000 ppm $(46.47 \mathrm{~cm})$ which was at par with $\mathrm{T}_{6}-\mathrm{CCC} @ 5000$ ppm $(41.09 \mathrm{~cm})$.

The significant increase in the height with $\mathrm{GA}_{3}$, which may be attributed to the action of gibberellins that promotes vegetative growth by way of cell division and cell elongation and this may have resulted in the increase of plant height. $\mathrm{GA}_{3}$ helps in increasing the photosynthesis activity in plants. This might have increased osmotic uptake of water and nutrients, by maintaining constant swelling force against the softening of cell walls. These results are nearby with the findings of Sen and Maharana (1972), Girwani (1988), Patel (1998), Dabas (2000), Pandya (2000), Patidar (2003), Sunitha (2007), Naidu (2011), Dobaria (2012), Yadav (2013), Palei (2016), Markam (2017), Kumar (2017).

In case of TRIA, as it has been reported to stimulates the growth of plant by enhancing the rates of photosynthesis, protein synthesis, still the growth was not significantly increased as compared to Control treatment effect. More concentration of TRIA showed visible plant growth which was reported by Wuryaningsih et al., (1997) in roses, while 2 ppm showed more height in marigold in the experiment conducted by Parihar (2006).

The growth retardant CCC significantly retarded the height of the plant. The 
internodal length was successfully suppressed with the treatment of Cycocel. The dose of $5000 \mathrm{ppm}$ of $\mathrm{CCC}$ retarded more height comparatively to $4000 \mathrm{ppm}$ of CCC, similar results were also observed by Jalagum (1991), Pandya (2000), Nath (2005), Kumar (2006), Sunitha (2007), Naidu (2011) in marigold, Joshi (2004) in China aster and Singh et. al. (2018) in chrysanthemum.

In case of NAA, the concentration of $10 \mathrm{ppm}$ showed more height followed by $20 \mathrm{ppm}$. The action of Naphthalic acetic acid which promotes growth by cell elongation and cell division also promoted height of marigold. Similar results were also noticed by Jalagum (1991), Patel (1998), Sunitha (2007) in marigold.

\section{Plant spread (cm)}

Data pertaining to plant spread of marigold as affected by different growth regulators are depicted in Table 2. The perusal of data revealed that at 30 DAT difference did not differ significantly. The difference is visibly non-significant. However, the plant spread was in the range of $22.88 \mathrm{~cm}$ in $\mathrm{T}_{8}$ to 23.57 $\mathrm{cm}$ in $\mathrm{T}_{9}$.

The significant differences in plant spread at 60 DAT were observed with plant growth regulators and their concentrations studied. On study of the data on plant spread in marigold revealed that maximum average plant spread was recorded in $\mathrm{T}_{1}-\mathrm{GA}_{3} @ 100$ ppm $(50.62 \mathrm{~cm})$ which was followed by $\mathrm{T}_{2}$ $\mathrm{GA}_{3} @ 200$ ppm $(48.89 \mathrm{~cm})$. The treatment with $\mathrm{GA}_{3} @ 100$ ppm was at par with $\mathrm{T}_{7}$ NAA@ 10 ppm $(48.13$ cm), T - TRIA @ 20 ppm (47.16 cm), T 8 - NAA @ 20 ppm (47.07 $\mathrm{cm}), \mathrm{T}_{9}$ - Control $(46.09 \mathrm{~cm}), \mathrm{T}_{4}$ - TRIA @ 30 ppm $(45.79 \mathrm{~cm})$. Treatment with $\mathrm{T}_{6}-\mathrm{CCC} @$ 5000 ppm reported lowest plant spread (36.38 cm) which was at par with $\mathrm{T}_{5}$ - CCC @ 4000 ppm $(37.88 \mathrm{~cm})$.
The plant growth regulators with different concentrations showed a visible difference in plant spread at 90 DAT. The maximum average spread was observed in $\mathrm{T}_{1}-\mathrm{GA}_{3}$ @ 100 ppm $(90.52 \mathrm{~cm})$ followed by $\mathrm{T}_{2}-\mathrm{GA}_{3} @$ 200 ppm $(88.96 \mathrm{~cm}), \mathrm{T}_{7}$ - NAA @ $10 \mathrm{ppm}$ $(88.80 \mathrm{~cm}), \mathrm{T}_{3}$ - TRIA @ 20 ppm $(84.42 \mathrm{~cm})$ and $\mathrm{T}_{8}$ - NAA@ 20 ppm $(87.14 \mathrm{~cm})$. The minimum plant spread was depicted in $\mathrm{T}_{6}$ CCC@ 5000 ppm $(41.37 \mathrm{~cm})$ which was at par with $\mathrm{T}_{5}$ - CCC @ 4000 ppm $(42.53 \mathrm{~cm})$.

At 120 DAT, maximum average plant spread was recorded in $\mathrm{T}_{1}-\mathrm{GA}_{3} @ 100$ ppm (92.52 $\mathrm{cm})$ which was at par with $\mathrm{T}_{2}-\mathrm{GA}_{3} @ 200$ ppm $(91.00 \mathrm{~cm})$ and $\mathrm{T}_{7}$ - NAA @ $10 \mathrm{ppm}$ $(90.49 \mathrm{~cm})$. The minimum plant spread was noticed in $\mathrm{T}_{6}-\mathrm{CCC} @ 5000$ ppm $(43.58 \mathrm{~cm})$ which was at par with $\mathrm{T}_{5}$ - CCC @ 4000 ppm $(44.24 \mathrm{~cm})$.

The plant spread increased statistically significant at all levels of $\mathrm{GA}_{3}$ at 60,90 and 120 DAT. Among the various concentrations of $\mathrm{GA}_{3}$ the maximum average plant spread was observed at $100 \mathrm{ppm}$. It reveals that 100 ppm was the optimum dose for maximum average plant spread. $\mathrm{GA}_{3}$ at optimum dose (100 ppm) might have enhanced the metabolic activities of the plant and influences the uptake of water and nutrients. Therefore, the plant spread has recorded increased magnitude. Similar results were recorded by Patel (1998), Dabas (2000), Pandya (2000), Naidu (2011) and Dobaria (2012).

The plant spread was also increased in TRIA treated plants. As a growth regulator TRIA increased the metabolic activities in plants and resulted in more plant spread. More or fewer same results were observed by Patidar (2003), Parihar (2006) in marigold.

The CCC growth retardant significantly reduced the growth of branches and 
consequently the spread of plants. The plants treated with CCC were more dwarf and bushy. With various concentrations comparable results were observed by Jalagum (1991), Pandya (2000), Joshi (2004), Nath (2005), Kumar et al., (2011). While Naidu (2011) noted that CCC enhanced the plant spread in marigold. The metabolic activities were improved by NAA too, the plant spread was seen more in NAA treated plants after $\mathrm{GA}_{3}$. The internodal length and length of branches was expressively increased by the process of cell division. Parallel results were observed by Jalagum (1991), Patel (1998), Dabas (2000), Sunitha (2007), Sherpa (2013) with different concentrations.

\section{Number of branches}

The data regarding number of branches per plant presented in marigold cv. Calcutta Marigold as affected by foliar application of various plant growth regulators are presented in Table 3. The perusal of data revealed that 30 DAT there was no significant difference in number of branches in various treatments, i.e. the data recorded was non-significant at 30 DAT. However, it was in the range of 7.60 in $\mathrm{T}_{1}$ to 7.73 in $\mathrm{T}_{3}$.

The statistically significant difference was noticed on number of branches at 60 DAT due to spraying of various plant growth regulators. The data indicated that maximum number of branches was recorded with $\mathrm{T}_{8}$ NAA @ 20 ppm (43.60) which was at par with $\mathrm{T}_{7}$ - NAA @ 10 ppm (41.87), T $-\mathrm{GA}_{3}$ @ 200 ppm (41.33) and $\mathrm{T}_{1}-\mathrm{GA}_{3} @ 100$ ppm (40.73). The minimum number of branches were recorded in $\mathrm{T}_{6}-\mathrm{CCC} @ 5000$ ppm (25.07) which was at par with $\mathrm{T}_{5}$ - CCC @ 4000 ppm (30.40).

At 90 DAT, maximum number of branches were observed in $\mathrm{T}_{1}-\mathrm{GA}_{3} @ 100$ ppm (53.21) which was at par with $\mathrm{T}_{7}$ - NAA @ 10 ppm (52.98), $\mathrm{T}_{2}-\mathrm{GA}_{3} @ 200 \mathrm{ppm}$ (52.83). $\mathrm{T}_{3}$ - TRIA@ 20 ppm (44.79), T 9 - Control and T 4 - TRIA@30 ppm (44.40) were on par with each other. The minimum number of branches were recorded in $\mathrm{T}_{5}$ - CCC @ 4000 ppm (40.03) which was at para with $\mathrm{T}_{6}-\mathrm{CCC}$ @ 5000 ppm (39.91).

At 120 DAT, maximum average number of branches (56.02) was observed in $\mathrm{T}_{1}-\mathrm{GA}_{3} @$ 100 ppm, which was at par with $\mathrm{T}_{2}-\mathrm{GA}_{3} @$ 200 ppm (55.98), T 7 - NAA @ 10 ppm (55.90), T 8 - NAA @ 20 ppm (55.88). The minimum number of branches were recorded in $\mathrm{T}_{6}$ - CCC @ 5000 ppm (45.13)which was at par with $\mathrm{T}_{5}$ - CCC @ 4000 ppm (45.11).

The variation of number of branches per plant might be due to the use of different compositions of different plant growth regulators. However, the different growth regulators used in experiment showed notable differences. $\mathrm{GA}_{3}$ significantly showed highest average number of branches with 100 ppm spray. Followed by maximum average branches was observed by $\mathrm{GA}_{3} 200$ ppm. The results are in close conformity with the findings of Patel (1998), Dabas (2000), Pandya (2000), Patidar (2003), Dobaria (2012), Yadav (2013), Palei et al., (2016) in marigold.

Like other vegetative parameters, TRIA also significantly increased the number of branches. The branches count was manifestly more than control treatment plants. Close results were also noted by Patidar (2003) and Parihar (2006) in marigold.

CCC as a growth retardant successfully reduced the plant height and spread, but it also recorded less number of branches. Moreover, the results were close to the results of Pandya (2000), Joshi (2004), Kumar (2006), Naidu (2011) in marigold. While it was recorded that highest number of branches 
were observed with CCC @ 2400 ppm, CCC @ 500 ppm and @ 1000 ppm by Kumar et al., (2011), Jalagum (1991), Wadgave (2016), respectively in marigold.

Likewise, other growth regulators, NAA significantly increased the number of branches, but it was noticed that there was decrease in number of branches with increase in concentrations of NAA. Similar results were also recorded by Dabas (2000), Sunitha (2007), Wadgave (2016), Bairwa et al., (2017) in marigold. Jalagum (1991) noticed that other vegetative parameters were effective but it induced less number of laterals in marigold.

\section{Number of leaves}

The results for average number of leaves per plant are presented in Table 4. The treatment effects are significantly seen in the data recorded.

The data collected at 30 DAT did not show any significant effect of PGR on number of leaves in marigold plant immediate after spray and the results at 30 DAT were nonsignificant. The data collected were in the range of 70.13 in $T_{5}$ to 71.20 in $T_{4}$.

At 60 DAT, among the growth regulators spray, $\mathrm{T}_{1}-\mathrm{GA}_{3} @ 100$ ppm recorded significantly maximum average number of leaves (233.73) which was at par with $\mathrm{T}_{2}$ $\mathrm{GA}_{3} @ 200$ ppm (232.53), T 7 - NAA @ 10 ppm (220.47), T - NAA @ 20 ppm (218.13). Minimum number of leaves were recorded in $\mathrm{T}_{6}$ - CCC@ 5000 ppm (182.67).

At 90 DAT, the difference between PGR treatments was visibly seen. Maximum average leaf count was noticed in $\mathrm{T}_{1}-\mathrm{GA}_{3} @$ 100 ppm (409.07) which was at par with $\mathrm{T}_{2}$ $\mathrm{GA}_{3} @ 200$ ppm (407.13), T 7 - NAA @ 10 ppm (393.27), T - NAA @ 20 ppm (391.13).
While minimum leaf count was recorded in $\mathrm{T}_{5}$ - CCC@4000 ppm (227.93) which was at par with $\mathrm{T}_{6}$ - CCC @ 5000 ppm (274.53).

Number of leaves count was increased at 120 DAT, difference amongst all treatment was recorded. The data obtained showed significant difference between the treatments which showed maximum average number of leaves in $\mathrm{T}_{1}-\mathrm{GA}_{3} @ 100$ ppm (420.60) which was at par with $\mathrm{T}_{2}-\mathrm{GA}_{3} @ 200$ ppm (419.20), $\mathrm{T}_{7}$ - NAA @ 10 ppm (402.93). While minimum number of leaves were observed in $\mathrm{T}_{5}$ - CCC @ 4000 ppm (290.13) and was at par with $\mathrm{T}_{6}$ - CCC @ 5000 ppm (286.73).

The leaves are the prime important functional units for photosynthesis, which greatly influence the growth and flower yield of crop. The variation in number of leaves per plant in different treatments may be due to effect of various concentrations of different plant growth regulators. As mentioned earlier in the result that different growth regulators have significantly affected the number of branches per plant, therewithal the leaves per plant were also significantly increased in $\mathrm{GA}_{3}$, the results were close to observation of Sen and Maharana (1972) in chrysanthemum, Girwani (1988), Patel (1998), Dabas (2000), Patidar (2003), Sunitha (2007), Naidu (2011), Dobaria (2012), Sherpa (2013), Palei et. al. (2016), Kumar (2017) in marigold.

The TRAI treatment effect was not much effective as comparative with control treatment plants. The results showed that the number of leaves per plant were lesser than $\mathrm{GA}_{3}$, NAA and Control treated plots. Patidar (2003) and Parihar (2006) noted that with 2 ppm TRIA showed maximum average leaves in marigold.

The number of leaves were reduced with number of branches with CCC treatment. The 
results were closer to findings of Sunitha (2007). The results obtained in marigold by Nath (2005) and Kumar et al., (2011) were unlike with CCC@1000 ppm and CCC @ 2400 ppm, respectively where they observed more number of leaves.
The NAA results were significantly noted a greater number of leaves with concentrations of NAA@10 and 20 ppm. The increased number of leaves observations were close to observations of Patel (1998), Naidu (2011), Palei et. al. (2016), Wadgave (2016), Bairwa et al., (2017) in marigold.

Table.1 Effect of plant growth regulators on plant height of marigold cv. Calcutta Marigold

\begin{tabular}{|c|c|c|c|c|c|}
\hline \multirow{2}{*}{\multicolumn{2}{|c|}{ Treatments }} & \multicolumn{4}{|c|}{ Average Plant height (cm) } \\
\hline & & 30 Days & 60 Days & 90 Days & 120 Days \\
\hline $\mathbf{T}_{1}$ & $\mathrm{GA}_{3} @ 100$ ppm & 28.31 & 50.74 & 79.90 & 82.26 \\
\hline $\mathbf{T}_{2}$ & $\mathrm{GA}_{3} @ 200$ ppm & 27.47 & 47.78 & 75.59 & 78.68 \\
\hline $\mathbf{T}_{\mathbf{3}}$ & TRIA@ 20 ppm & 25.88 & 47.73 & 72.90 & 76.92 \\
\hline $\mathbf{T}_{4}$ & TRIA@ @ 30 ppm & 23.90 & 43.52 & 68.43 & 71.36 \\
\hline $\mathbf{T}_{5}$ & CCC @ 4000 ppm & 21.00 & 34.03 & 44.87 & 46.47 \\
\hline $\mathbf{T}_{6}$ & CCC@ 5000 ppm & 22.63 & 35.77 & 39.10 & 41.09 \\
\hline $\mathbf{T}_{7}$ & NAA@10 ppm & 24.82 & 50.99 & 77.45 & 79.06 \\
\hline $\mathbf{T}_{8}$ & NAA@ 20 ppm & 23.53 & 48.18 & 73.29 & 75.41 \\
\hline $\mathbf{T}_{9}$ & Control & 25.92 & 50.50 & 73.61 & 75.57 \\
\hline & Mean & 24.83 & 45.47 & 67.24 & 69.65 \\
\hline & S. Em. \pm & 1.58 & 1.75 & 2.02 & 1.85 \\
\hline & C.D. at $5 \%$ & NS & 5.24 & 6.07 & 5.55 \\
\hline
\end{tabular}

Table.2 Effect of plant growth regulators on plant spread of marigold cv. Calcutta Marigold

\begin{tabular}{|c|c|c|c|c|c|}
\hline \multirow{2}{*}{ Treatments } & \multicolumn{4}{|c|}{ Average plant spread (cm) } \\
\cline { 3 - 6 } & 30 Days & 60 Days & 90 Days & 120 Days \\
\hline $\mathbf{T}_{\mathbf{1}}$ & GA $_{3} @ 100 \mathrm{ppm}$ & 23.24 & 50.62 & 90.52 & 92.52 \\
\hline $\mathbf{T}_{\mathbf{2}}$ & GA $_{\mathbf{3}} @ 200 \mathrm{ppm}$ & 23.03 & 48.89 & 88.96 & 91.00 \\
\hline $\mathbf{T}_{\mathbf{3}}$ & TRIA @ 20 ppm & 22.96 & 47.16 & 87.42 & 89.38 \\
\hline $\mathbf{T}_{\mathbf{4}}$ & TRIA @ 30 ppm & 23.54 & 45.79 & 85.72 & 87.89 \\
\hline $\mathbf{T}_{\mathbf{5}}$ & CCC @ 4000 ppm & 22.95 & 37.88 & 42.53 & 44.24 \\
\hline $\mathbf{T}_{\mathbf{6}}$ & CCC @ 5000 ppm & 23.10 & 36.38 & 41.37 & 43.58 \\
\hline $\mathbf{T}_{\mathbf{7}}$ & NAA @ 10 ppm & 23.18 & 48.13 & 88.80 & 90.49 \\
\hline $\mathbf{T}_{\mathbf{8}}$ & NAA @ 20 ppm & 22.88 & 47.07 & 87.14 & 89.83 \\
\hline $\mathbf{T}_{\mathbf{9}}$ & Control & 23.57 & 46.09 & 85.59 & 87.02 \\
\hline & Mean & 23.16 & 45.34 & 77.56 & 79.55 \\
\hline & S. Em. \pm & 1.12 & 2.00 & 1.14 & 0.74 \\
\hline & C.D. at 5\% & NS & 6.00 & 3.41 & 2.21 \\
\hline
\end{tabular}


Table.3 Effect of plant growth regulators on number of branches of marigold cv. Calcutta Marigold

\begin{tabular}{|c|c|c|c|c|c|}
\hline \multirow{2}{*}{\multicolumn{2}{|c|}{ Treatments }} & \multicolumn{4}{|c|}{ Average number of branches } \\
\hline & & \multirow{2}{*}{$\begin{array}{c}30 \text { Days } \\
7.73\end{array}$} & \multirow{2}{*}{$\begin{array}{c}\text { 60 Days } \\
40.73\end{array}$} & \multirow{2}{*}{$\begin{array}{c}90 \text { Days } \\
53.21\end{array}$} & \multirow{2}{*}{$\begin{array}{c}120 \text { Days } \\
56.02\end{array}$} \\
\hline $\mathbf{T}_{1}$ & $\mathrm{GA}_{3} @ 100$ ppm & & & & \\
\hline $\mathbf{T}_{2}$ & $\mathrm{GA}_{3} @ 200$ ppm & 7.67 & 41.33 & 52.83 & 55.98 \\
\hline $\mathbf{T}_{\mathbf{3}}$ & TRIA@20 ppm & 7.60 & 37.93 & 44.79 & 49.93 \\
\hline $\mathbf{T}_{4}$ & TRIA@ @30 ppm & 7.73 & 35.40 & 44.40 & 49.80 \\
\hline $\mathbf{T}_{\mathbf{5}}$ & CCC @ 4000 ppm & 7.73 & 30.40 & 40.03 & 45.13 \\
\hline $\mathbf{T}_{6}$ & CCC @ 5000 ppm & 7.73 & 25.07 & 39.91 & 45.11 \\
\hline $\mathbf{T}_{7}$ & NAA@ 10 ppm & 7.67 & 41.87 & 52.98 & 55.90 \\
\hline $\mathbf{T}_{8}$ & NAA@ @20 ppm & 7.73 & 43.60 & 52.13 & 55.88 \\
\hline \multirow[t]{4}{*}{$\mathbf{T}_{9}$} & Control & 7.73 & 37.73 & 44.66 & 49.35 \\
\hline & Mean & 7.70 & 37.12 & 47.19 & 51.46 \\
\hline & S. Em. \pm & 0.06 & 1.84 & 0.24 & 0.20 \\
\hline & C.D. at $5 \%$ & NS & 5.52 & 0.72 & 0.59 \\
\hline
\end{tabular}

Table.4 Effect of plant growth regulators on number of leaves of marigold cv. Calcutta Marigold

\begin{tabular}{|c|c|c|c|c|c|}
\hline \multirow{2}{*}{\multicolumn{2}{|c|}{ Treatments }} & \multicolumn{4}{|c|}{ Average number of leaves } \\
\hline & & \multirow{2}{*}{$\begin{array}{c}30 \text { Days } \\
71.00\end{array}$} & \multirow{2}{*}{\begin{tabular}{|c|}
60 Days \\
233.73 \\
\end{tabular}} & \multirow{2}{*}{$\begin{array}{c}90 \text { Days } \\
409.07\end{array}$} & \multirow{2}{*}{$\begin{array}{r}120 \text { Day } \\
420.60\end{array}$} \\
\hline $\mathbf{T}_{1}$ & $\mathrm{GA}_{3} @ 100$ ppm & & & & \\
\hline $\mathbf{T}_{2}$ & $\mathrm{GA}_{3} @ 200$ ppm & 70.73 & 232.53 & 407.13 & 419.20 \\
\hline $\mathbf{T}_{3}$ & TRIA@20 ppm & 70.33 & 204.00 & 330.07 & 335.07 \\
\hline $\mathbf{T}_{4}$ & TRIA@30 ppm & 71.20 & 203.00 & 328.47 & 333.07 \\
\hline $\mathbf{T}_{5}$ & CCC@ @4000 ppm & 70.13 & 184.40 & 277.93 & 290.13 \\
\hline $\mathbf{T}_{6}$ & CCC@ 5000 ppm & 70.27 & 182.67 & 274.53 & 286.73 \\
\hline $\mathbf{T}_{7}$ & NAA@10 ppm & 70.33 & 220.47 & 393.27 & 402.93 \\
\hline $\mathbf{T}_{8}$ & NAA@ 20 ppm & 70.40 & 218.13 & 391.13 & 400.53 \\
\hline \multirow[t]{4}{*}{$\mathbf{T}_{9}$} & Control & 70.40 & 198.67 & 370.80 & 386.80 \\
\hline & Mean & 70.53 & 208.62 & 353.60 & 363.90 \\
\hline & S. Em. \pm & 0.52 & 7.79 & 6.06 & 6.16 \\
\hline & C.D. at $5 \%$ & NS & 23.35 & 18.17 & 18.46 \\
\hline
\end{tabular}


Table.5 Effect of plant growth regulators on average fresh weight and dry weight of plant of marigold cv. Calcutta Marigold

\begin{tabular}{|c|c|c|c|}
\hline Treatments & Treatment details & $\begin{array}{c}\text { Average plant } \\
\text { fresh weight } \\
\text { (g/plant) }\end{array}$ & $\begin{array}{c}\text { Average plant } \\
\text { dry weight } \\
\text { (g/plant) }\end{array}$ \\
\hline $\mathbf{T}_{\mathbf{1}}$ & $\mathrm{GA}_{\mathbf{3}}$ @ $100 \mathrm{ppm}$ & 190.37 & 22.84 \\
\hline $\mathbf{T}_{\mathbf{2}}$ & $\mathrm{GA}_{\mathbf{3}} @ 200 \mathrm{ppm}$ & 189.17 & 22.70 \\
\hline $\mathbf{T}_{\mathbf{3}}$ & TRIA @ 20 ppm & 170.13 & 20.42 \\
\hline $\mathbf{T}_{\mathbf{4}}$ & TRIA @ 30 ppm & 169.00 & 20.28 \\
\hline $\mathbf{T}_{\mathbf{5}}$ & CCC @ 4000 ppm & 110.47 & 13.26 \\
\hline $\mathbf{T}_{\mathbf{6}}$ & CCC @ 5000 ppm & 108.83 & 13.06 \\
\hline $\mathbf{T}_{\mathbf{7}}$ & NAA @ 10 ppm & 171.47 & 20.58 \\
\hline $\mathbf{T}_{\mathbf{8}}$ & NAA @ 20 ppm & 170.53 & 20.46 \\
\hline $\mathbf{T}_{\mathbf{9}}$ & Control & 169.90 & 20.38 \\
\hline & Mean & 161.10 & 19.33 \\
\hline & S. Em. $\mathbf{\pm}$ & 0.52 & 0.10 \\
\hline & C.D. $\mathbf{a t ~ 5 \%}$ & 1.57 & 0.31 \\
\hline
\end{tabular}

\section{Fresh weight of plant (g/plant)}

The fresh weight of the plant indicates the biomass production of the crop. The data regarding the fresh weight which differed from each other due to application different PGR treatments is cited in Table 5.

The fresh weight of plants ranged from $190.37 \mathrm{~g} / \mathrm{plant}$ to $108.83 \mathrm{~g} / \mathrm{plant}$. Among the different treatments the maximum average fresh weight was recorded in $\mathrm{T}_{1}-\mathrm{GA}_{3} @ 100$ ppm (190.37 g/plant) and was at par with $\mathrm{T}_{2}$ $\mathrm{GA}_{3} @ 200$ ppm (189.17 g/plant). The data was followed by $\mathrm{T}_{7}$ - NAA @ 10 ppm (171.47 g/plant) and was at par with $\mathrm{T}_{8}$ - NAA @ 20 ppm (170.53 g/plant), T - TRIA @ 20 ppm (170.13 g/plants) and $\mathrm{T}_{9}$ - Control (169.90 $\mathrm{g} /$ plant). The minimum fresh weight was perceived in $\mathrm{T}_{5}$ - CCC @ 4000 ppm (110.47 g/plant) which was at par with $\mathrm{T}_{6}-\mathrm{CCC} @$ (108.83 g/plant).

The effect of different concentrations of $\mathrm{GA}_{3}$, TRIA, CCC and NAA on average fresh weight of plants interpreted in Table 5. showed that, the average fresh weight of whole plant was directly associated with number of branches and leaves. The increase in height, spread, number of branches and leaves enhanced the fresh weight of the plant. The increased weight might be the result of plant growth regulators used. The maximum average fresh weight of marigold plant was noted with $\mathrm{GA}_{3}$ treated plants. The results were similar to Patel (1998), Dabas (2000), Pandya (2000), Patidar (2003), Naidu (2011), Dobaria (2012), Yadav (2013), Rajhansa (2014), Markam, (2017), Kumar (2017) in marigold.

The effect of TRIA, more or else had same fresh weight as that of control or water sprayed plants. The treatment was not much effective considering vegetative growth parameters as compared to control i.e. water spray. Patidar (2003) recorded higher fresh weight in plants treated with TRIA @ 2.5 ppm. While same results were recorded by Parihar (2006) with TRIA @ 2 ppm in marigold. 
The retardant CCC successfully reduced the vegetative growth of plants like height, spread, branches and leaves. Hence the fresh weight was significantly low than any other treatments. The similar results were recorded by Jalagum (1991), Joshi (2004), Nath (2005), Naidu (2011). However, Wadgave (2016) recorded more number of branches in CCC @ $1000 \mathrm{ppm}$, the fresh weight was also recorded more in the same.

The fresh weight was significantly increased in NAA treated plants as it increased the vegetative growth of plants after $\mathrm{GA}_{3}$. The height, spread, number of branches, leaves significantly increased the fresh weight of the plants. The fresh weight was recorded more in NAA @ 10 ppm than $20 @$ ppm. Similar results were observed by Jalagum (1991) with NAA @ 100 ppm, Patel (1998), Naidu (2011). Bairwa et.al. (2017) recorded highest fresh weight in marigold with the plants treated with NAA@ 300 ppm which was of much higher concentration than the present experiment.

\section{Dry weight of plant (g/plant)}

The data regarding average dry weight of plant are presented in Table 5, revealed significant difference between different treatments had different dry weight of plant.

The average dry weight of plant ranges from $22.84 \mathrm{~g} /$ plant to $13.06 \mathrm{~g} /$ plant. The maximum average dry weight was perceived in $\mathrm{T}_{1}-\mathrm{GA}_{3}$ @ $100 \mathrm{ppm}(22.84 \mathrm{~g} /$ plant $)$ was statistically at par with $\mathrm{T}_{2}-\mathrm{GA}_{3} @ 200$ ppm (22.70 g/plant). These treatments were followed by $\mathrm{T}_{7}$ - NAA @ $10 \mathrm{ppm}(20.58 \mathrm{~g} / \mathrm{plant})$ and was at par with $\mathrm{T}_{8}$ - NAA @ 20 ppm (20.46 g/plant), $\mathrm{T}_{3}$ TRIA @ 20 ppm (20.42 g/plants), $\mathrm{T}_{9}$ Control (20.38 g/plant), $\mathrm{T}_{4}$ - TRIA @ 30 ppm (20.28 g/plant). The minimum dry weight was noted in $\mathrm{T}_{5}$ - CCC @ 4000 ppm (13.26 $\mathrm{g} /$ plant) and was at par with $\mathrm{T}_{6}$ - CCC @ 5000 (13.06 g/plant).
The dry weight was linked with fresh weight. Almost all the moisture was removed and the fresh matter was dried to the extinct. The observations were parallel to fresh weight of same plants. The maximum average dry weight was recorded in $\mathrm{GA}_{3}$ treated plants. The same results were observed by Patel (1998), Dabas (2000), Pandya (2000), Patidar (2003), Naidu (2011), Dobaria (2012), Yadav (2013), Rajhansa (2014), Markam, (2017), Kumar (2017) in marigold.

The dry weight of plants treated with TRIA was recorded. The results found were more or less same as control plants dry weight and was not similar to the results of Patidar (2003) and Parihar (2006), as they recorded maximum average dry weight than control plants.

The dry weight was equivalent to the fresh weight and was significantly lower than any other treatments. The similar results were recorded in marigold by Jalagum (1991), Nath (2005), Naidu (2011) and Joshi (2004) in China aster. Wadgave (2016) recorded a maximum average fresh weight, the dry weight was also recorded more in marigold.

The dry weight of NAA treated plants was equivalent to the fresh weight and was significantly more. Same results were observed by Jalagum (1991) with NAA @ 100 ppm, Patel (1998), Naidu (2011) and Bairwa et al., (2017) in marigold.

\section{References}

Alam, A.U., Crouch, J.R. and Creger C.R. (1968). Fatty acid composition of Xanthophyll esters of Tagetes erecta petals. Lipids 3: 184.

Anonymous (2014). Package of Practices of Commercial Flower Crops, Tamil Nadu Agricultural University, Coimbatore, Published on site icar.gov.in. pgs: 1-23. 
Anonymous (2019). Statistic Report of Area and Production by National Horticultural Board, Horticulture Statistic Division, Department of Agriculture, Cooperation and Farmers Welfare, Ministry of Agriculture and Farmers Welfare, Government of India.

Anonymous (2019). Statistic Report of Floriculture Export, Agril. and Processed Food Products Export Development Authority (APEDA 2018-19), Ministry of Commerce and Industry, Government of India.

Anonymous (2019). Statistic Report of Horticulture Crops presented in research review meeting of Dr. BSKKV, Dapoli, 2019.

Dabas, H. K. (2000). Effect of growth regulators on growth, flowering and flower yield of African marigold (Tagetes erecta L.). Thesis Master of Science, Indira Gandhi Krishi Vishwavidyalaya, Raipur., pgs. 128.

Dobaria, P. D., (2012). Effect of plant growth regulators on vegetative growth, flowering and yield of marigold (Tagetes erecta L.) cv. Pusa Narangi Gainda. M.Sc. Thesis JAU, Junagadh. $\mathrm{Pg}-116$.

Girwani, A. (1988). Effect of plant growth regulators and micro nutrients on growth, flowering and yield of Marigold. (Tagetes erecta L.). Thesis submitted to Acharya N. G. Ranga Agricultural University, Rajendra Nagar, Hyderabad.

Jalagum, A. (1991). Effect of plant growth regulators on growth, flowering and yield of marigold (Tagetes erecta L.). MSc. Thesis. Acharya N.G. Ranga Agricultural University, Rajendra Nagar, Hyderabad. pgs- 101.

Joshi, V. (2004). Studies on the effect of certain plant growth regulators on growth and flowering of China aster. Master of Science Thesis. Acharya N.G.
Ranga Agriculture University, Rajendra Nagar, Hyderabad.

Kumar, M. (2006). Effect of nutrients, pinching and growth retardants on growth, flowering and yield of African marigold (Tagetes erecta L.). Ph.D. Thesis. Chaudhary Charan Singh Haryana Agriculture University, Hisar. pgs -112 .

Kumar, A., Kumar, J., Singh, M. B., Rajbeer J.P. and Ram Nathi (2011). Effect of plant growth regulators on growth, flowering and yield of African marigold (Tagetes erecta L.) cv. Pusa Narangi Gainda, Asian J. Hort., 6 (2): 418-422.

Nath, K. (2005). Effect of application of Maleic Hydrazide and Cycocel on the yield and quality of marigold (Tagetes erecta L.). Master of Science Thesis. Indira Gandhi Krishi Vishwavidyalaya, Raipur. pgs -86 .

Naidu, J. H. (2011). Effect of plant growth retardants, growth regulators and spacing on vegetative and flower yield of African Marigold (Tagetes erecta) cv. Pusa Narangi Gainda. Master of Science Thesis. Andhra Pradesh Horticultural University.

Patel, J. K. (1998). Effect of plant growth regulators on vegetative and reproductive growth of French marigold (Tagetes patula L.) var. "Local". MSc. thesis. Department of Horticulture N. M. College of Agriculture, Navsari Agricultural University. Pgs -120 .

Pandya, P. N. (2000). Effect of growth regulators on growth, yield and vase life of African marigold (Tagetes erecta L.) cv. 'Lemon Yellow'. MSc. Thesis. AAU, Anand. pgs - 73 .

Patidar, D. (2003). Effect of triacontanol and gibberellin on the performance of African marigold (Tagetes erecta L.). M.Sc. Thesis, JNKVV, Jabalpur. pgs 114.

Parihar, P. S. (2006). Effect of phosphorus 
and triacontanol on the growth, development and productivity of African marigold (Tagetes erecta L.) cv. Pusa Narangi Gainda.

Palei, S., Das, A. K., Dash, D. K. (2016). Effect of plant growth regulators on growth. flowering and yield attributes of African marigold (Tagetes erecta L.). International Education and Research Journal - 44., 2 (6).

Rajhansa, K. C. (2014). Studies on effect of pinching and growth regulators on growth, flowering and yield of African marigold. Ph.D. Thesis submitted to Indira Gandhi Krishi Vishwavidyalaya, Raipur.

Sen, S.K. and Maharana T. (1972). Effect of some regulators on the growth and flowering of Chrysanthemum $(C$. morifolium Ram.) Indian J. Hort., 29 (2): 236-240.

Sherpa, N. (2013). Effect of plant growth regulators on growth, development and flowering of African marigold (Tagetes erecta L.). MSc. thesis. Uttar Banga Krishi Vishwavidyalaya.

Skogen, D., Erisken, A. B. and Nilsen, S. (1982). Effect of triacontanol on production and quality of flowers of
Chrysanthemum morifolium Ramat. Scientia Horticulturae, 18 (1): 87-92.

Sunayana, S., Meera Manjusha, A. V., Rajagopalan, A., Madala, A. (2017). Effect of growth retardants (Alar and Cycocel) on flower yield and carotenoid content in African marigold (Tagetes erecta L.) varieties. Journal of Tropical Agriculture, 55.

Sunitha, H. M. (2007). Effect of plant population, nutrition, pinching and growth regulators on plant growth, seed yield and quality of African marigold (Tagetes erecta L.). Master of Science thesis submitted to University of Agricultural Sciences GKVK, Bangalore. pgs -146 .

Wadgave, A. R. (2016). Effects of pinching and plant growth regulators on growth and yield of African marigold (Tagetes erecta L.) cv. Calcutta Orange in Krishna Command Area MSc thesis submitted to University of Horticultural Sciences, Bagalkot.

Wuryanigsih and Kusumo, S. S. (1997). Application of triacontanol to improve yield and quality of rose flower. Jurnal Hortikultura (Indonesia). 7(2): 673-677.

\section{How to cite this article:}

Narute, T. T., Y. R. Parulekar and Narute, T. K. 2020. Effect of Plant Growth Regulators on Vegetative Parameter of Marigold cv. Calcutta Marigold under Konkan Conditions. Int.J.Curr.Microbiol.App.Sci. 9(10): 3985-3997. doi: https://doi.org/10.20546/ijcmas.2020.910.458 